\title{
Incorporating Public Insecurity Indicators: A New Approach to Measuring Social Welfare in Mexico
}

Oscar A. Martinez-Martinez ${ }^{1}$, Ana-Maria Vazquez-Rodriguez ${ }^{2}$, Margaret Lombe ${ }^{3}$, Pablo Gaitan-Rossi ${ }^{1}$

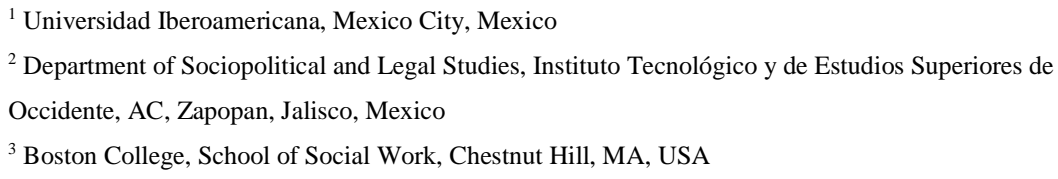

\begin{abstract}
This study presents evidence on the utility of including public insecurity indicators when assessing Social Welfare in Mexico. It estimates two multidimensional indices of social welfare using the DP2 method. The two measures $\left(D P_{2} a\right.$ index and $D P_{2} b$ index) contain the following categories: (1) material welfare, (2) economic well-being, (3) subjective well-being, and (4) social capital. For the second, we included an additional category, (5) public insecurity, and examined its effect on social welfare. The results show that inclusion of indicators of insecurity, crime victimization, and homicides had a negative effect on social welfare within states. Specifically, trust in people, network membership, satisfaction with life, and happiness where reduced. Our results suggest that public insecurity should be a key consideration in the understanding of social welfare in Mexico.
\end{abstract}

Keywords: social welfare, public insecurity, welfare policy, Mexico

\section{Introduction}

Social Welfare (SW) is a multidimensional and contextual concept. It is generally adjusted to reflect the prevailing social realities of a given context (Grasso \& Canova, 2008). It consists of a material dimension, including economic indicators such as income, employment, level of schooling, and access to social security services (Di Pasquale, 2008; Mæstad \& Norheim, 2012). The other dimension of social welfare is subjective and includes elements such as happiness and satisfaction with life (Diener, 1994, 2000).

The concept of SW not only takes into account the different aspects of people's lives but also requires an ongoing revision and assessment of what each category means for a country, territory, or community (Tonon, 2012). This assessment is said to be essential in that it helps capture the needs and indicators that accurately reflect local realities (Noll, 2011). Indeed, research in this area has helped uncover useful indicators of SW such as social capital (Berigan \& Irwin, 2011; Grootaert et al. 2002; Sarracino, 2013), use of technology 
(Cuenca \& Rodríguez, 2010; Kaino, 2012; Zhao, 2009), and access to culture and leisure (Berigan \& Irwin, 2011; Gaddis 2013; Haller et al. 2013; Jaeger, 2009). Guided by this premise-the utility of using contextspecific indicators of SW to measure complex phenomenon such as living conditions - this study presents evidence on the relevance of including public insecurity when measuring SW in Mexico. The relationship between public insecurity and SW at the state level is also provided.

This study is important in that Mexico has experienced a steady growth in violence (Leenen \& Cervantes-Trejo, 2014). The numbers of Mexicans who have faced some type of crime increased from $24 \%$ in 2010 to $28.2 \%$ in 2015 (ENVIPE, 2014), this translates into 28,200 victims per 100,000 inhabitants. Moreover, only one in ten crimes is reported, and of these, only one in 100 leads to a sentencing; meaning that only one out of every 1,000 reported crimes is punished (Magaloni \& Razu, 2016). These numbers persist despite the macro-strategy of the "National Program to Prevent Violence and Delinquency" launched by Enrique Peña Nieto's government (2012-2018) and the numerous actions taken by municipal governments in 2014 to prevent violence/crime in the 73 locations known for their high levels of crime and insecurity (México Evalúa, 2015).

To our knowledge, little attention has been devoted to understanding the effects of violence or crime on social welfare. Studies have centered mainly on how violence and crime affect social and economic performance and on locations that have high crime rates (Ackerman \& Murray, 2004). Indeed, there is a dearth in evidence at the state level on how public-insecurity indicators interact or are included in a multidimensional measurement of wellbeing. This study attempts to rectify this gap in knowledge by using context-specific indicators of public insecurity and connecting them to social welfare. The manuscript is divided into four sections; first, we review the literature that focuses on the effects of public insecurity on social wellbeing. Second, the method is given, describing the indicators used and the technique applied to measure social wellbeing. Third, the results are shown, having included public-insecurity indicators and their repercussions on SW. Finally, the results are discussed and conclusions are provided.

\section{Review of the Literature}

\section{Effects of public insecurity on welfare}

The inclusion of public safety as one of the dimensions of social welfare has been under consideration for some time (Diprose, 2007). This is evident in prominent publications including the Report of the Commission on the Measurement of Economic Development and Social Progress (Stiglitz et al., 2009), the Organization for Economic Co-operation and Development's (OECD) “How's Life?” proposal (OECD, 2011), and the Mexican report (OECD, 2015). The pertinence of including public insecurity in accessing SW relates to the relationship between the two. Specifically, security/insecurity, objective welfare, and subjective welfare 
are generally considered as parts of a whole (Wills-Herrera et al., 2011; Gasper, 2005). For example, evidence suggests that public insecurity is connected to neighborhood crime and police indifference (Alvarado, 2010), which in turn is inversely related to social welfare (Wills-Herrera et al., 2011).

Measuring insecurity and its effects on social welfare in Latin America has become especially important partly because of growing social instability (Kaino, 2012; Farhadi et al., 2012; Briceño-León et al., 2008; Imbusch et al., 2011) and the need to capture the complexity of the local reality. Indeed, insecurity is said to negatively affect physical (DeVerteuil, 2015; Torche \& Villarreal, 2014) and mental health (Stafford et al., 2007; Wilson-Genderson \& Pruchno, 2013). It is also said to be inversely correlated to educational attainment (Caudillo \& Torche, 2014), income (Sen, 1999), and the overall happiness of individuals and communities in violence-inclined environments (Grahamy \& Chaparro, 2011).

\section{Individual-level effects (victims and offenders)}

Generally, compared to those who have not suffered from crime victims of crime tend to perceive greater risk and a sense of loss of personal control (Hale, 1996; Russo et al., 2008; Shippee, 2012). Consequently, victims of crime report negative effects of crime on happiness (Graham \& Chaparro, 2011) and life satisfaction (Hanslmaier, 2013). Furthermore, crime victimization is said to have far-reaching consequences, such as involvement in delinquency and the reproduction of violence (Hay \& Evans, 2006). Nevertheless, reactions to the act of violence are not homogenous (Bunch et al., 2014). Traumatic effects may be linked to psychological attributes such as self-efficiency (Bosmans \& Velden, 2015); interaction attributes like social connections (Fox \& Bouffard, 2015), and social traits, such as poverty (Lowe et al., 2014).

\section{Community-level effects: The perception of public insecurity}

Classic studies on fear of crime tend to highlight the relationship between victimization and fear. These studies suggest that people who are not in direct contact with crime tend to exhibit high levels of anxiety and insecurity. In addition, scholars argue that perceptions of social disorder are often connected to crime and feelings of insecurity (Skogan, 2015; Skogan \& Maxfielcd, 1981). Furthermore, the paradox of victimization shows that people exhibiting higher levels of fear are more likely to become victims of crime (Pearson \& Breetzke, 2014). For example, in Mexico, feelings of insecurity tend to be higher among women, people with little schooling, older people, individuals who do not trust their neighbors and the police, those who perceive a lack of social order, and people who have been victimized by violence (Vilalta, 2013).

On the other hand, the prospect of moving up socially—through secure employment, living in a county characterized by rule of law, or of living in a rural area is positively associated with perceptions of security (Graham \& Chaparro, 2011). The foregoing discussion is suggestive and may point to the fact that perceptions 
of insecurity are built into the collective imagination as a result of criminal activities, police actions along with the daily acts of neighbors (Alvarado, 2010). Indeed, feelings of insecurity are heightened when crime affects wide sectors of the population and when only a small number of the people who demand justice see it served (De la Barreda, 2007).

\section{Structural-level effects of homicides (state-level effects)}

Homicide rates are generally used as indicators the degree of violence in a given location (Galster, 2012; Sampson et al., 2002). Accordingly, several studies have shown the negative connection between this indicator and community violence (Fowler et al., 2009). Furthermore, there is some evidence suggesting that people living in communities characterized by violence resulting in high homicide rates exhibit different types of affectation. For example, children show reduced cognitive abilities (Sharkey \& Faber, 2014); lower highschool graduation rates among youth (Wodtke et al., 2011), and substance use and abuse (Wright et al., 2013).

The literature reviewed in this discussion provides a sound background from which to review the relationships advanced by this study. Specifically, we analyze the levels of state-level welfare by using contextspecific indicators, and we investigate the relationship between public insecurity and SW at the state level.

\section{Methods}

\section{Measures}

Social welfare was measured using a synthetic index made up of five categories: (1) material welfare, (2) economic welfare, (3) subjective welfare, (4) social capital, and (5) public insecurity. Indicators for each category were chosen taking into account the criteria established by Martinez-Martinez et al. (2016): (1) their consistency with previous research (Bellani \& D'Ambrosio, 2011; Diener, 1994; Gaitán, 2006; Grootaert, et al., 2002; Jaeger, 2009; London et al., 2014; Luhmann et al., 2011); (2) their availability and level of representation for the categories of interest in the 32 states in the country; and (3) each indicator being mutually exclusive. The selected indicators are described on Table 1, and Table 4 of the appendix shows all of the indicators by state given in the unit of measurement from Table 1.

Table 1. Categories and Indicators

\begin{tabular}{|l|l|l|l|}
\hline Category & Indicator & Measurement & Source \\
\hline \multirow{5}{*}{ Material Welfare $^{\mathrm{h} i}$} & Educational Lag & $\begin{array}{l}\text { Percentage of the Population that did } \\
\text { not meet required basic education } \\
\text { level }{ }^{\mathrm{a}} \text { or did not attend a formal } \\
\text { education center. }\end{array}$ & $\begin{array}{l}\text { MCS-ENIGH } \\
2014\end{array}$ \\
\cline { 2 - 4 } & Food insecurity & $\begin{array}{l}\text { Percentage of the population with } \\
\text { food insecurity }\end{array}$ & $\begin{array}{l}\text { MCS-ENIGH } \\
2014\end{array}$ \\
\cline { 2 - 4 } & Social Security & $\begin{array}{l}\text { Percentage of the population with no } \\
\text { work benefits or access to a worker } \\
\text { contribution or non-worker } \\
\text { contribution pension system }\end{array}$ & $\begin{array}{l}\text { MCS-ENIGH } \\
2014\end{array}$ \\
\hline
\end{tabular}




\begin{tabular}{|c|c|c|c|}
\hline & Access to health services & $\begin{array}{l}\text { Percentage of the population with no } \\
\text { health coverage at a public or private } \\
\text { institution }\end{array}$ & $\begin{array}{l}\text { MCS-ENIGH } \\
2014\end{array}$ \\
\hline & $\begin{array}{l}\text { Quality of and spaces in } \\
\text { the home }\end{array}$ & $\begin{array}{l}\text { Percentage of the population in } \\
\text { homes with dirt floors, weak roofs } \\
\text { and walls, and where there is } \\
\text { crowding }\end{array}$ & $\begin{array}{l}\text { MCS-ENIGH } \\
2014\end{array}$ \\
\hline & $\begin{array}{l}\text { Basic services in the } \\
\text { home }\end{array}$ & $\begin{array}{l}\text { Percentage of the population in } \\
\text { homes without: electricity, drainage, } \\
\text { or water and with a chimney if they } \\
\text { use wood or coal to cook. }\end{array}$ & $\begin{array}{l}\text { MCS-ENIGH } \\
2014\end{array}$ \\
\hline Economic Welfare ${ }^{\mathrm{h}} \mathrm{i}$ & Income & $\begin{array}{l}\text { Percentage of the population earning } \\
\text { less than the minimum wage }\end{array}$ & $\begin{array}{l}\text { MCS-ENIGH, } \\
2014\end{array}$ \\
\hline \multirow{2}{*}{ Subjective Welfare ${ }^{\text {hi }}$} & Satisfaction in life & Scale of satisfaction in life & BIARE 2014 \\
\hline & Happiness & Scale of happiness & BIARE 2014 \\
\hline \multirow{2}{*}{ Social Capital $^{\mathrm{hi}}$} & Network membership & $\begin{array}{l}\text { Index of belonging to neighborhood, } \\
\text { sports, cultural, political, and } \\
\text { religious groups }{ }^{\text {f }}\end{array}$ & BIARE 2014 \\
\hline & Trust in people & $\begin{array}{l}\text { Number of people someone would } \\
\text { count on in an emergency or need for } \\
\text { help. }\end{array}$ & BIARE 2014 \\
\hline \multirow{3}{*}{ Public Insecurity ${ }^{\mathrm{i}}$} & Perception of Insecurity & $\begin{array}{l}\text { Percentage of the population } 18 \text { and } \\
\text { over perceiving insecurity in town or } \\
\text { county }\end{array}$ & ENVIPE 2014 \\
\hline & Victims of Crime & $\begin{array}{l}\text { Percentage of population } 18 \text { and over } \\
\text { that has been a victim of a crime }\end{array}$ & ENVIPE 2014 \\
\hline & Homicides & $\begin{array}{l}\text { Percentage of deaths by homicide } \\
\text { compared to total violent deaths }\end{array}$ & INEGI 2013 \\
\hline \multicolumn{4}{|c|}{ 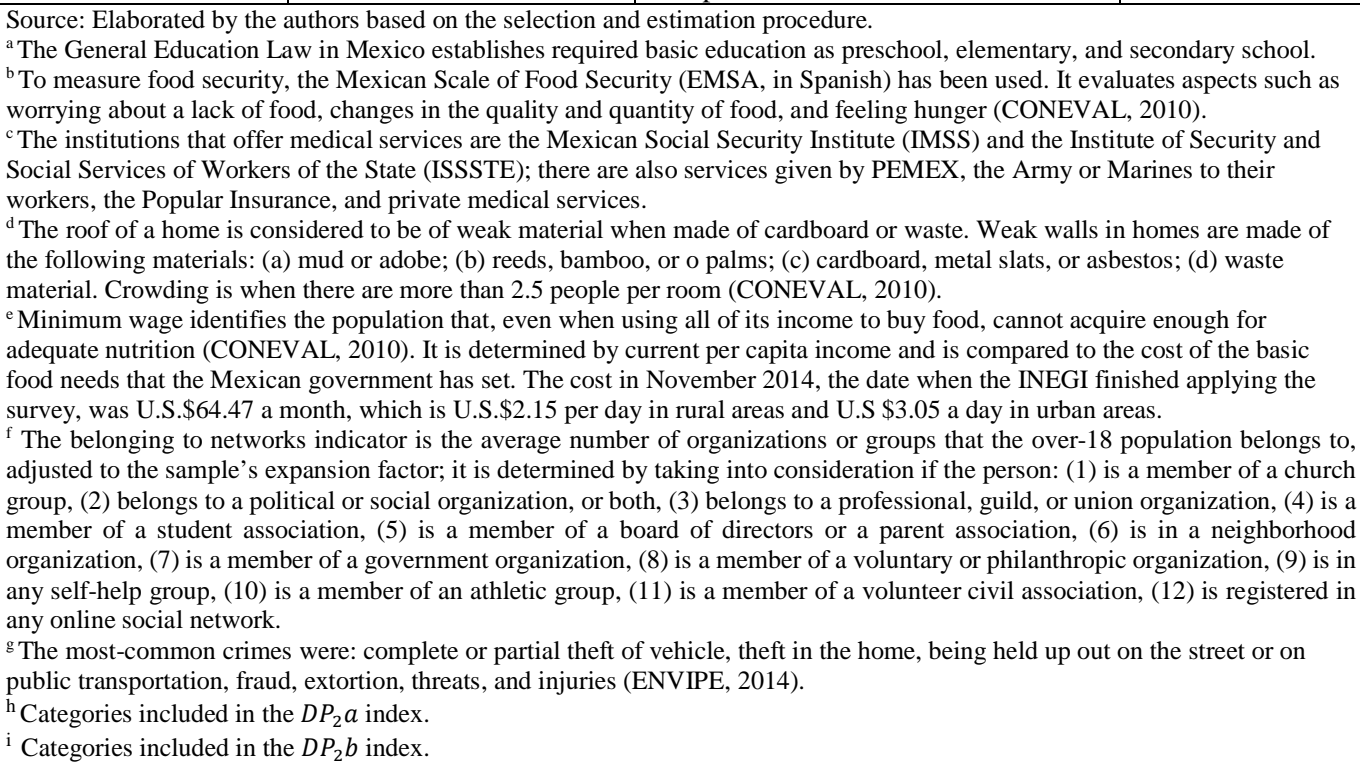 } \\
\hline
\end{tabular}

\section{Description of the Data}

The indicators are drawn from four datasets obtained from the Mexican National Institute of Statistics (2014), Geography, and Computer Science (INEGI). When there was no data for that year, the nearest year was used. ${ }^{1}$ The first dataset, the "Module of Socioeconomic Conditions of the National Survey of Home Income and Spending" (MCS-ENIGH, 2014) contains information on the distribution, amount, and structure

\footnotetext{
${ }^{1}$ For example, in the case of homicides.
} 
of the home income and spending. The second, the National Survey of Victims and Perceptions of Public Security (ENVIPE, 2014) explores the level of victimization directly experienced by people and/or homes. The third, the Self-Reported Welfare Survey (BIARE, 2014) measures subjective welfare of individuals and different dimensions of social capital. Finally, the data on homicides were obtained from INEGI (2013) mortality statistics.

Based on the aforementioned indicators, a database was built where indicators with a negative sign were noted if they had a negative correlation to welfare ${ }^{2}$; in this way, the highest values in absolute numbers meant a decrease in the general level of welfare (Cuenca \& Rodríguez, 2010).

The technique used to create the index was the Pena-Trapero distance method $\left(D P_{2}\right)$, which condenses several partial indicators into a synthetic one ${ }^{3}$ to create a ranking between the analyzed territories, allowing for intertemporal comparisons of identical territorial units. Doing so requires comparison in absolute terms of differences of each indicator of a territorial unit $x_{j i}$, with the respective indicator of territorial unit reference base $x_{* i}$; in our case, the reference base unit is a theoretical scenario representing a territory with the lowest values seen in the indicators used (Cuenca \& Rodríguez, 2010).

To define $\mathrm{DP}_{2}, n$ partial indicators of $r$ different territories are considered first, and then the variables are defined.

- $\quad x_{j i}$ is the value of indicator $i$ in territorial unit $j$;

- $x_{* i}$ is the value of indicator $i$ in the reference-base territorial unit, which will be compared to indicator $i$ of all of the territorial units. Usually, $x_{* i}$ is the lowest value of indicator $i$ in the $r$ territorial units;

- $X_{*}=\left(x_{* 1}, x_{* 2}, \ldots, x_{* n}\right)$ is called the reference vector and has the value of all of the indicators of the reference-base territorial unit.

Next, the distance indicator $\left(D P_{2}\right)$ for territory $j$ is calculated as

$$
D P_{2_{j}}=\sum_{i=1}^{n}\left\{\left(\frac{d_{i}}{\sigma_{i}}\right)\left(1-R_{i, i-1, i-2, \ldots, 1}^{2}\right)\right\}
$$

where

- $d_{i}=\left|x_{j i}-x_{* i}\right|$ is the difference in absolute terms between indicator $i$ of territory $j$ and indicator $i$ of the reference territory;

- $\sigma_{i}$ is the standard deviation of indicator $i$

\footnotetext{
${ }^{2}$ The indicators of subjective welfare and social capital were the only ones not captured with a negative sign.

${ }^{3}$ The ranking created with the $D P_{2}$ brings together a series of traits that are priority in synthetic indices: uniqueness, homogeneity, monotony, existence and determination, invariance related to the reference base, transitivity, comprehensiveness, and additivity (PenaTrapero, 2009).
} 
- $\quad R_{i, i-1, i-2, \ldots, 1}^{2}$ is the coefficient of the determination of the linear regression of $X_{i}$ over $X_{i-1}, X_{i-2}, \ldots, X_{1}$ and represents the goodness of fit of the model to predict $X_{i} . R_{1}^{2}=0$ is defined.

- $\quad\left(1-R_{i, i-1, i-2, \ldots, 1}^{2}\right)$ is the correlation factor that shows the variance part of $X_{i}$ not explained by the linear regression, which the indicator weighs with useful information not included before.

The $D P_{2}$ is the sum of the distances between the value in variable $i$ of the territory versus the value of the hypothetical territory $j$ (the lowest value of that variable in all of the territories), weighed by the standard deviation of indicator $i$ and corrected by the non-explained variance of $X_{i}$. Modelling was conducted with $\mathrm{R}$ software.

Because the aim of the study is to show the importance of including public insecurity in measuring SW, two indices measuring welfare were created with the information in Table 1 and were later compared. The first index $\left(\mathrm{DP}_{2} a\right)$ contains the indicators from the categories (1) material welfare, (2) economic wellbeing, (3) subjective wellbeing, and (4) social capital; in the second $\left(D P_{2} b\right)$ we included an additional category, (5) public insecurity, to examine its differentiated effect on the measure of social welfare.

To define how public insecurity affects SW at the states, Ivanovic's (1974) test was used

$$
D C_{i}=\frac{2}{m(m-1)} \sum_{j, l>j}^{k_{i}} m_{j i} m_{l i}\left|\frac{x_{j i}-x_{l i}}{\bar{X}_{l}}\right|
$$

where $m$ is the number of territories, and $m_{j i}$ is the absolute frequency of $x_{j i}$; it is used to calculate the discriminating power of each indicator $i$ in territorial unit $j$ and to break down the $D P_{2}$ in each territory. The results are shown in the next section. First, we present the synthetic measurement of welfare through a ranking in indices $D P_{2} a$ and $D P_{2} b$; next we display the results showing the contribution of each category to the measure; finally, we present the behavior of the public insecurity indicators at the state level.

\section{Results}

\section{Synthetic Measurement of welfare: Ranking among states}

The results of the measure of social welfare using the $D P_{2}$ technique in columns three and four are shown on Table 2; this reveals the ranking among the 32 states in Mexico, as well as their position according to level of welfare (very high, high, medium, and low). The ranking was obtained by calculating the quartiles of the data; the fixed cut point system of the Index of Human Development was not used because there is no base year. 
Table 2 Welfare Indices

\begin{tabular}{|c|c|c|c|c|c|}
\hline \multirow[t]{2}{*}{ Level } & \multirow[t]{2}{*}{ State } & \multirow[t]{2}{*}{$D P_{2 a}$} & \multirow[t]{2}{*}{$D P_{2 b}$} & \multicolumn{2}{|c|}{ Ranking } \\
\hline & & & & $D P_{2 a}$ & $D P_{2 b}$ \\
\hline \multirow{8}{*}{ Very High } & Nuevo León & 17.82 & 20.85 & 1 & 1 \\
\hline & Sonora & 16.26 & 20.05 & 2 & 2 \\
\hline & Coahuila & 16.15 & 18.98 & 3 & 8 \\
\hline & Tamaulipas & 15.93 & 18.99 & 4 & 7 \\
\hline & Querétaro & 14.82 & 19.84 & 5 & 3 \\
\hline & Chihuahua $^{\mathrm{a}}$ & 14.70 & 16.98 & 6 & 11 \\
\hline & Aguascalientes & 14.61 & 19.46 & 7 & 4 \\
\hline & Baja California Sur & 14.11 & 19.20 & 8 & 5 \\
\hline \multirow{8}{*}{ High } & Mexico City & 14.03 & 16.40 & 9 & 16 \\
\hline & Baja California & 14.02 & 16.87 & 10 & 12 \\
\hline & Colima & 13.97 & 17.78 & 11 & 10 \\
\hline & Durango & 13.27 & 16.49 & 12 & 14 \\
\hline & Nayarit & 13.24 & 17.79 & 13 & 9 \\
\hline & Yucatán ${ }^{\mathrm{b}}$ & 13.07 & 19.06 & 14 & 6 \\
\hline & Quintana Roo & 13.06 & 16.64 & 15 & 13 \\
\hline & San Luis Potosí & 13.01 & 16.48 & 16 & 15 \\
\hline \multirow{8}{*}{ Medium } & Sinaloa & 12.68 & 15.74 & 17 & 17 \\
\hline & Jalisco & 12.40 & 15.38 & 18 & 20 \\
\hline & Zacatecas & 12.24 & 15.44 & 19 & 19 \\
\hline & Campeche & 11.30 & 15.60 & 20 & 18 \\
\hline & Guanajuato & 10.80 & 14.39 & 21 & 22 \\
\hline & Mexico $^{\mathrm{a}}$ & 10.56 & 11.21 & 22 & 26 \\
\hline & Morelos $^{\text {a }}$ & 10.31 & 12.34 & 23 & 25 \\
\hline & Tlaxcala & 10.07 & 14.43 & 24 & 21 \\
\hline \multirow{8}{*}{ Low } & Hidalgo $^{b}$ & 9.19 & 13.36 & 25 & 23 \\
\hline & Tabasco $^{\mathrm{b}}$ & 9.00 & 12.36 & 26 & 24 \\
\hline & Veracruz & 6.95 & 10.46 & 27 & 27 \\
\hline & Puebla & 6.36 & 10.27 & 28 & 28 \\
\hline & Chiapas & 5.76 & 10.09 & 29 & 29 \\
\hline & Michoacán & 5.70 & 8.88 & 30 & 30 \\
\hline & Guerrero & 5.12 & 7.21 & 31 & 32 \\
\hline & Oaxaca & 4.27 & 7.84 & 32 & 31 \\
\hline \multicolumn{6}{|c|}{$\begin{array}{l}\text { Source: Authors, based results of the estimation. } \\
\text { a States where level of wellbeing goes down after including public-insecurity indicators. } \\
\text { b States where level of wellbeing goes up after including public-insecurity indicators. }\end{array}$} \\
\hline
\end{tabular}

The results of index $\mathrm{DP}_{2} a$ show that Nuevo León is positioned in first place (17.82) in the welfare index, followed by Sonora (16.26). At the other end of the spectrum, Michoacán (5.70), Guerrero (5.12), and Oaxaca (4.27) have the lowest welfare indices in the country; the latter, Oaxaca, is more than four times behind Nuevo León, which shows a good deal of disparity in welfare. The order on the $D P_{2} b$ measures remains the same for the states with the highest welfare. However, with respect to low-ranked states, Guerrero remains the lowest in rank; almost three times behind Nuevo León.

When ranks of the two indices are compared, eight states are in the same position. However, when indicators of insecurity were included, 11 states change their position, indicating a decrease in welfare; Guanajuato and Guerrero moved down only one position, while Baja California, Durango, Jalisco, and Morelos moved down two positions, and Tamaulipas lost three. The states most affected in their level of welfare with the inclusion of insecurity were the State of Mexico (moved down by four positions), and Coahuila and 
Chihuahua (moved down by five positions). It is worth noting that Mexico City went down seven positions, going from the $9^{\text {th }}$ to the $16^{\text {th }}$ place.

On the other hand, 13 states moved up in the $D P_{2} b$ ranking with the inclusion of insecurity; Colima, San Luis Potosí, and Oaxaca moved up by one position; Querétaro, Quintana Roo, Campeche, Hidalgo, and Tabasco moved up by two positions; and Aguascalientes, Baja California Sur, and Tlaxcala moved up by three positions. Yucatán moved up the most (8 positions); suggesting that the insecurity indicators had a positive effect on welfare for this state.

Despite the inclusion of indicators of public insecurity, 26 states did not change their position on the welfare ranking (very high, high, medium, and low welfare) as registered in $D P_{2} a$ index. Only six states moved down from their initial position: Chihuahua from very high to high, and Mexico and Morelos (both from midlevel to low). On the contrary, the welfare levels for Yucatán (high to very high) and Hidalgo and Tabasco (low to medium) changed position with respect to welfare; indicating the effect of public insecurity indicators on welfare.

\section{Effects of public insecurity on welfare}

A correlation factor was used to estimate the contributions of each partial indicator to the results of synthetic indices $D P_{2} a$ and $D P_{2} b$ previously shown. This estimator is useful in showing the real contribution of each indicator by eliminating redundant information from the others (see Table 3, columns 3 and 5). The correlation coefficients (columns 4 and 6) show the level of absolute correlation of each indicator with the synthetic index.

Table 3 Correction and correlation factors

\begin{tabular}{|c|c|c|c|c|c|}
\hline Category & Partial Indicator & $\begin{array}{c}\mathrm{DP}_{2} a \\
\text { Correction } \\
\text { Factor } \\
\end{array}$ & $\begin{array}{l}\text { Correlation } \\
\text { Coefficient }\end{array}$ & $\begin{array}{c}D P_{2} b \\
\text { Correction } \\
\text { Factor }\end{array}$ & $\begin{array}{l}\text { Correlation } \\
\text { Coefficient }\end{array}$ \\
\hline \multicolumn{6}{|c|}{ Material welfare } \\
\hline & Social Security & 1 & 0.94 & 1 & 0.88 \\
\hline & Access to health services & 0.58 & 0.68 & 0.62 & 0.72 \\
\hline & Food insecurity & 0.43 & 0.70 & 0.43 & 0.67 \\
\hline & Educational Lag & 0.28 & 0.83 & 0.28 & 0.75 \\
\hline & Access to basic services in the home & 0.27 & 0.80 & 0.27 & 0.72 \\
\hline & Quality of and spaces in the home & 0.23 & 0.73 & 0.22 & 0.66 \\
\hline \multicolumn{6}{|c|}{ Economic welfare } \\
\hline & Income & 0.26 & 0.85 & 0.26 & 0.79 \\
\hline \multicolumn{6}{|c|}{ Subjective Welfare } \\
\hline & Satisfaction with life & 0.52 & 0.69 & 0.51 & 0.65 \\
\hline & Happiness & 0.37 & 0.56 & 0.31 & 0.52 \\
\hline \multicolumn{6}{|c|}{ Social Capital } \\
\hline & Network membership & 0.49 & 0.54 & 0.49 & 0.59 \\
\hline & Trust in people & 0.42 & 0.53 & 0.49 & 0.56 \\
\hline \multicolumn{6}{|c|}{ Public Insecurity } \\
\hline & Perception of insecurity & --- & --- & 0.55 & 0.51 \\
\hline & Victims of crime & --- & --- & 0.40 & 0.08 \\
\hline & Homicides & --- & --- & 0.38 & 0.19 \\
\hline
\end{tabular}


The results of the $\mathrm{DP}_{2} a$ correction factor show that social security is the indicator that contributes the most information to the creation of the index; it has the highest correlation to the index (0.94). The secondmost-important indicator was access to health services, contributing about $58 \%$ of new information to the index, followed by satisfaction with life, which contributes $52 \%$. Other indicators with a high level of correlation were network membership, food insecurity, and trust in people (49\%, 43\%, and 42\%, respectively). Factors contributing the least were income (26\%) and quality of spaces in the home (23\%), although both had high correlations to the index. Regarding the correlation coefficient, the second-highest indicators were income and educational lag $(0.85 \mathrm{y} 0.83)$, followed by access to basic services in the home $(0.80)$.

Similarly, social security had the highest contribution and the highest correlation for the $D P_{2} b$, index (0.88). The second-ranked indicator was access to health services, contributing $62 \%$ to the synthetic index. The perception of insecurity had the third-highest contribution, 55\%, moving satisfaction with life down to the fourth place. Once again, network membership and trust in people had high correction factors (49\% each). The two indicators that contributed the least to this index were income, at 26\% (although it has a high correlation to the index), and quality of homes and living spaces, at $22 \%$.

These results suggest that including the public-safety category affected the correction and correlation coefficients all the indicators (see Table 3). For example, access to health care and trust in people moved up in their contribution to the index; along the same lines, the three indicators of public insecurity contributed significantly to the creation of the index. Meanwhile, satisfaction with life, happiness, and quality of and spaces in homes had a minimal contribution.

Contribution of the public-insecurity indicators to understanding of state-level welfare

To examine the weight of each indicator at the state level, indices $D P_{2} a$ and $D P_{2} b$ were broken down using Ivanovic's (1974) test. Tables 5 and 6 (appendices), show the heterogeneity of the indicators in each territory.

Findings from the $\mathrm{DP}_{2} \mathrm{a}$ index are presented on Table 5 show that social security, access to health services, trust in people, food insecurity, and satisfaction with life had the most effect on welfare at the state level. Some indicators had zero value, suggesting that they did not contribute to the construction of welfare on the $D P_{2} a$ index. The zero-value indicators appeared mainly in the states of Chiapas (social security, educational lag, and income); Oaxaca (satisfaction with life, happiness, and basic services in the home); and Michoacán (access to health services and happiness). 
Results from the $D P_{2} b$ index are presented on Table 6 suggest that the indicators that were important for understanding welfare at the state level were social security, access to health services, and victims of crime. As was the case with the $\mathrm{DP}_{2} a$ index, some indicators had a value of zero on this measure, adding nothing to the construction of welfare. This was observed mainly in Chiapas (social security, educational lag, and income); Oaxaca (satisfaction with life, happiness, and basic services in the home); Guerrero (homicides and quality of and spaces in the home); Michoacán (access to health services and happiness); and México (perception of insecurity and victims of crime).

The different effects of public insecurity at the state level suggest that measuring social welfare is a complex undertaking. For this reason, its indicators (perception of insecurity, victims of crime, and homicides), may contribute to and affect welfare in each state differently (Table 6). Furthermore, the observed high contribution of public insecurity to welfare in Querétaro, Baja California Sur, and Yucatán may be explained by their low levels of perception of insecurity (ENVIPE, 2015). Specifically, in the case of Yucatán, the contribution of public insecurity to welfare is higher than social security and access to health services. On the other hand, in the State of Mexico the value of public insecurity is zero (Table 6), suggesting that this indicator did not contribute to the construction of welfare. Similarly, at slightly above zero, the relationship between public insecurity and welfare in the states of Michoacán, Tamaulipas, and Morelos can be explained by the high level of perception of insecurity that characterize these states (ENVIPE, 2015).

We also note that victims of a crime had a high contribution to welfare in states such as Chiapas and Oaxaca (see Table 6), which can be explained by the low percentage of people who have been victims of a crime in these states (ENVIPE, 2015). On the other hand, in the State of México the contribution of this indicator to welfare was zero, meaning that it did not contribute to state welfare. This observation could be explained by the high percentage of victims of crime (ENVIPE, 2015). Baja California, Mexico City, and Jalisco reflect a similar situation.

Finally, Table 6 shows that in Yucatán, Aguascalientes, Querétaro, and Baja California Sur, homicides contributed highly to the construction of welfare. This may be explained by the low percentage of people who die as a result of homicide (INEGI, 2013). To the contrary, in Guerrero the observed figure, zero, suggests that this indicator did not contribute to welfare. Moreover, Chihuahua, Morelos, and Sinaloa have less than a percentage point; these results are as would be expected given that these states have the highest percentage of deaths by homicide in the country. 


\section{Discussion}

Results of this study reveal the complexity of accessing welfare in Mexico and similar contexts. The measures utilized (such as income, household conditions, educational lag, happiness levels, network membership, and satisfaction with life), for the most part, show consistency in assessing welfare across states.

These results underscore the usefulness of using context specific measures when assessing welfare. They further, point to the need for better-designed context specific indicators and policies that are guided by sound evidence.

In this study, we noted that none of the income indicators significantly contribute to welfare; they did not even feature among the most relevant indicators as suggested by previous research (see e.g. RodríguezMartín, 2011; Cuenca \& Rodríguez, 2010). This contrasting finding deserves attention and may imply that in certain contexts, income may not be a good reflection of welfare. It could be that the levels of engagement in activities associated with income generation may be too low for income to matter in understanding welfare.

Another point of interest relates to the impact of public insecurity on welfare. Specifically, this study observed that welfare in all states was affected by public insecurity, but this effect was heterogeneous and had a different weight. For example, in some states, indicators of welfare such as network membership, happiness, and satisfaction with life, move down in importance with the inclusion of public insecurity. The observed results may point to the fact that public insecurity, in Mexico, may be reflected in the fear of losing stability or even one's life; negatively affecting subjective welfare (Wills-Herrera et al., 2011).

Furthermore, as observed by others, perceptions of public insecurity may be interpreted as a breakdown of social networks, impacting how people engage with such institutions (Carballo, 2013). On the other hand, having strong social ties and networks may help foster a sense of security in the face of crime, contributing to perceptions of decrease public insecurity (Vilalta, 2013). Overall, the evidence, indicated in the foregoing discussion, suggests that the direct or indirect impact of public insecurity on welfare may require different levels of interventions and that these may vary by state.

We also noted that states with both very high levels of wellbeing and the lowest levels of poverty were affected the most by inclusion of public-insecurity indicators (CONEVAL, 2015). Indeed, as revealed by Tables 2 and 6, the position of states like Coahuila, Tamaulipas, Chihuahua, and Mexico City was altered (they moved down) probably as a result of the weakening of indicators in the social-capital and subjective wellbeing categories. This observation is noteworthy and may point to the detrimental effect of public insecurity on welfare even in affluent locations. With respect to the lowest-ranked states, which in fact reported higher poverty levels, e.g., Chiapas, Michoacán, Guerrero, and Oaxaca, although public insecurity did not 
significantly alter their position on welfare, we cannot claim the measure did not have an effect on welfare. Indeed, as exemplified in the case of Guerrero, a state with the highest percentage of homicides in the country, which moved from $31^{\text {st }}$ to $32^{\text {nd }}$ place on the measure of welfare when public insecurity included; public insecurity may be important in explaining welfare at the state level. Most importantly, the observed results might mean that states positioned in the middle of the welfare raking may be affected the most by the inclusion of public insecurity. These observations point to need for more-refined theories of security/insecurity and welfare for middle and low income locations.

\section{Study limitations}

A number of limitations are acknowledged. First, this study relies heavily on indicators and a database built from four different surveys with state representation. A potential challenge for future research is to use a single survey covering various welfare indicators with statistical representation at the municipal level and with a longitudinal perspective to allow comparison over time. Regarding the indicators utilized, even though inclusion of the category of public insecurity negatively impacted items such as belonging to networks, trust, happiness, and satisfaction with life, these findings may suggest that subjective indicators are at times affected by the problem of adaptive preferences (Crettaz \& Suter, 2013).

Another limitation relates to the cross-sectional nature of this study, which restrict our ability to make causal inferences of insecurity on welfare. Similarly, it is likely that some indicators of insecurity, especially perception of insecurity, may be biased because of the number of exogenous variables that affect it in rural and urban areas. Therefore, it is possible that the effect size may be underestimated in some cases.

Despite the observed limitations, this study has merit. It reveals the need for inclusion of measures of public insecurity that allow understanding of ways in which individuals and communities may be affected (directly or indirectly), as well as how they may react, share their experiences, and survive in highly violent contexts.

\section{Conclusion}

To conclude, it is important to acknowledge that violence in Mexico has become more complexmoving from being a rural southern phenomenon to a more-urban reality, often linked to organized crime (Magaloni \& Razu, 2016). This observation points to the need to utilize research evidence assessing the link between poverty, wellbeing, and crime (particularly crime related to drug trafficking). Inclusion of indicators

of public insecurity when assessing welfare may be an essential step in this direction. As has been observed (Esquivel, 2015), the use of such measures allow for accurate investigation of multiple dimensions and may 
facilitate examination of conditions under which social interaction, social practices, and the formation of networks interact to impact individual, family, and community life.

Further, results of this study suggest that 24 of the 32 states showed alteration in their ranking with regards to welfare when public-insecurity indicators were included. States whose welfare ranking moved down upon inclusion of the public security indicator are classified into three blocks for the purpose of this discussion. Public insecurity, in the first block, which is made up of states such as Tamaulipas, Morelos, Michoacán, Guerrero, Chihuahua, Coahuila, and Durango, may be attributed to drug trafficking and organized crime. Moreover, these states are also characterized by high rates of homicide and perception of insecurity (ENVIPE, 2014; INEGI, 2013).

With respect to the second block, public insecurity may result mainly from different types of crime e.g., theft (at home, the street/public transportation), fraud, extortion, and threats. In fact, states like Baja California, Jalisco, the State of Mexico, and Mexico City, are at the top in the nation with regards to two indicators - victims of crime and perception of security (ENVIPE, 2014).

The third block consists of Oaxaca. Although we are unable to specify the primary sources of insecurity for this state, we can speculate that perceptions of insecurity come mainly from social conflicts characterized by constant blocking of highways, barricades, ${ }^{4}$ and general civil unrest.

Overall, results indicated present evidence on the need to take into account public insecurity as an important dimension of social welfare especially in contexts characterized by high levels of violence, such as Mexico (Diprose, 2007). Indeed, perception of welfare need to be re-conceptualized to reflect contextual needs/challenges. This is essential for the enactment of evidence-informed policy decisions with great potential to address welfare and public safety concerns.

\section{References}

Ackerman, W. V., \& Murray, A. T. (2004). Assessing spatial patterns of crime in Lima, Ohio. Cities. Retrieved from http://dx.doi.org/10.1016/j.cities.2004.07.008

Alvarado, A. (2010). Inseguridad pública, participación ciudadana y gobernanza: la Ciudad de México en la última década. Estudios Sociológicos de El Colegio de México, 28(84), 941-963.

Bellani, L., \& D’Ambrosio, C. (2011). Deprivation, Social Exclusion and Subjective Well-Being. Social Indicators Research, doi:10.1007/s11205-010-9718-0

Berigan, N., \& Irwin, K. (2011) Culture, Cooperation, and the General Welfare. Social Psychology Quarterly, doi:10.1177/0190272511422451

\footnotetext{
${ }^{4}$ Barricades ocurr when people block streets and sidewalks, not allowing people to walk by or public transportation to drive through.
} 
BIARE. (2014). Encuesta de Bienestar Autorreportado. Resource document. México: Instituto Nacional de Estadística Geografía e Informática. Retrieved October 13, 2015, from

http://www.inegi.org.mx/inegi/contenidos/investigacion/Experimentales/Bienestar/

Bosmans, W. G., \& Velden, V. P. (2015). Longitudinal interplay between posttraumatic stress symptoms and coping self-efficacy: A four-wave prospective study. Social Science \& Medicine. doi:10.1016/j.socscimed.2015.04.007

Briceño-León, R., Villaveces, A., \& Concha-Eastman, A. (2008). Understanding the uneven distribution of the incidence of homicide in Latin America. International journal of epidemiology, doi:10.1093/ije/dyn 153

Bunch, J., Clay-Warner, J., \& Mcmahon-Howard, J. (2014). The Effects of Victimization on Routine Activities. Criminal Justice and Behavior, doi:10.1177/0093854813508286

Carballo, A. (2013). Capital social como estrategia para enfrentar la condición de pobreza. Análisis sobre el caso del pueblo de Santa Fe. Tesis de Maestría. Mexico City: Universidad Iberoamericana.

Caudillo, M. L., \& Torche, F. (2014). Exposure to Local Homicides and Early Educational Achievement in Mexico. Sociology of Education, doi:10.1177/0038040714523795

CONEVAL. (2010). Metodología para la medición multidimensional de la pobreza en México. México City: National Council for the Evaluation of Social Development Policy.

CONEVAL. (2015). Informe de pobreza en México 2014. México City: National Council for the Evaluation of Social Development Policy.

Cuenca, E. \& Rodríguez, J. (2010). Medición de las disparidades entre indicadores asociados al bienestar social en los países menos adelantados (PMA) de Asia. Revista de Economía Mundial, 25, 83-108.

Crettaz, E. \& Suter, C. (2013) The Impact of Adaptive Preferences on Subjective Indicators: An Analysis of

Poverty Indicators. Social Indicators Research, doi:10.1007/s11205-013-0388-6

De la Barreda, L. (2007). Miedo. Revista Letras Libres, 9(97), 26-30.

DeVerteuil, G. (2015) Conceptualizing violence for health and medical geography. Social Science \& Medicine, doi:10.1016/j.socscimed.2015.01.018

Di Pasquale, E. (2008). La operacionalización del concepto de Bienestar Social: un análisis comparado de distintas mediciones. Observatorio Laboral Revista Venezolana, 1(2), 17-42.

Diener, E. (2000) SubjectiveWell-Being. The Science of Happiness and a Proposal for a National Index. American Psychologist, http://dx.doi.org/10.1037/0003-066X.55.1.34.

Diener, E. (1994) Assessing subjective well-being: Progress and opportunities. Social Indicators Research, doi: 10.1007/BF01207052.

Diprose, R. (2007). Safety and Security: A Proposal for Internationally Comparable Indicators of Violence. Oxford Poverty and Human Development Initiative.

Esquivel Hernández, G. (2015). Desigualdad extrema en México. Concentración del poder económico y político. México: Oxfam.

ENVIPE. (2014). Encuesta Nacional de Victimización y Percepción de la Seguridad Pública. Resource document. México: Instituto Nacional de Estadística Geografía e Informática. Retrived October 10, 2015, from http://www.inegi.org.mx/est/contenidos/proyectos/encuestas/hogares/regulares/envipe/envipe2014/default.as px.

Farhadi, M., Ismail. R., \& Fooladi, M. (2012). Information and Communication Technology Use and Economic Growth, doi: 10.1371/journal.pone.0048903. 
Fowler, P. J., Tompsett, C. J., Braciszewski, J. M., Jacques-Tiura, A. J., \& Baltes, B. B. (2009). Community violence: A meta-analysis on the effect of exposure and mental health outcomes of children and adolescents. Development and Psychopathology, doi:10.1017/S0954579409000145

Fox, K. A., \& Bouffard, L. A. (2015) Violent Victimization Vulnerability: Testing a Conceptual Model of Personality, Social, and Community Factors. Deviant Behavior, doi:10.1080/01639625.2014.977201

Gaddis, S. (2013) The influence of habitus in the relationship between cultural capital and academic achievement. Social Science Research, doi: 10.1016/j.ssresearch.2012.08.002.

Galster, G. C. (2012). The Mechanism(s) of Neighbourhood Effects: Theory, Evidence, and Policy Implications. Neighborhood Effects Research: New perspectives, doi: 10.1007/978-94-007-2309-2_2

Gasper, D. (2005). Securing humanity: Situating 'human security' as concept and discourse. Journal of Human Development, doi: 10.1080/14649880500120558

Graham, C., \& Chaparro, J. C. (2011). Inseguridad, salud y bienestar. una exploración basada en encuestas sobre la felicidad en América Latina y el Caribe. Washington, DC: Inter-American Development Bank.

Grasso, M., \& Canova, L. (2008) An Assessment of the Quality of Life in the European Union Based on the Social Indicators Approach. Social Indicators Research, doi: 10.1007/s11205-007-9158-7

Grootaert, C., Oh, G. \& Swamy, A. (2002) Social Capital, Household Welfare and Poverty in Burkina Faso. Journal of African Economies, doi: 10.1093/jae/11.1.4.

Hale, C. (1996). Fear of crime: A review of the literature. International Review of Victimology, doi: $10.1177 / 026975809600400201$

Haller, M., Hadler, M., \& Kaup, G. (2013). Leisure Time in Modern Societies: A New Source of Boredom and Stress? Social Indicators Research, doi: 10.1007/s11205-012-0023-y.

Hanslmaier, M. (2013) Crime, fear and subjective well-being: How victimization and street crime affect fear and life satisfaction. European Journal of Criminology, doi:10.1177/1477370812474545

Hay, C., \& Evans, M. M. (2006). Violent victimization and involvement in delinquency: Examining predictions from general strain theory. Journal of Criminal JusticeJ, doi:10.1016/j.jcrimjus.2006.03.005

Imbusch, P., Misse, M., \& Carrion, F. (2011). Violence research in Latin America and the Caribbean: A literature review. Journal of Conflict and Violence, 5(1), 87-154.

INEGI. (2013). Estadísticas de mortalidad en México. Resource document. México: Instituto Nacional de Estadística Geografía e Informática. Retrieved May 6, 2015, from

http://www.inegi.org.mx/est/contenidos/proyectos/registros/vitales/mortalidad/

Ivanovic, B. (1974). Comment établiruneliste des indicateurs de développement. [How to establish a list of development indicators]. Revue de statistiqueappliquée, 22(2), 37-50.

Jaeger, M. (2009) Equal Access but Unequal Outcomes: Cultural Capital and Educational Choice in a Meritocratic Society. Social Forces, doi: 10.1353/sof.0.0192

John, P. (2005) The contribution of volunteering, trust, and networks to educational performance. Policy Studies Journal, doi:10.1111/j.1541-0072.2005.00136.x

Kaino, L. (2012). The use of ICT in achieving the Millennium Development Goals (MDGs) in Universities. South African Journal of Higher Education, 26(3), 503-514.

Leenen, I., \& Cervantes-Trejo, A. (2014) Temporal and geographic trends in homicide and suicide rates in Mexico, from 1998 through 2012. Aggression and Violent Behavior, doi:10.1016/j.avb.2014.09.004 
London, R., Pastor, M. Jr., Servon, L., Rosner, R., \& Wallace, A. (2014) The Role of Community Technology Centers in Promoting Youth Development. Journal Youth \& Society, doi: 10.1177/0044118X09351278.

Lowe, S. R., Galea, S., Uddin, M., \& Koenen, K. C. (2014) Trajectories of Posttraumatic Stress Among Urban Residents. American Journal of Community Psychology. doi:10.1007/s10464-014-9634-6

Luhmann, M., \& Schimmack, U., \& Eid, M. (2011) Stability and variability in the relationship between subjective well-being and income. Journal of Research in Personality, doi: 10.1016/j.jrp.2011.01.004.

Magaloni, B., \& Razu, Z. (2016). Mexico in the Grip of Violence. Current History, 115(778), 57-62.

Martinez-Martinez, O., Lombe, M., Vazquez-Rodriguez, A., \& Coronado-Garcia, M. (2016) Rethinking the Construction of Welfare in Mexico: Going beyond the Economic Measures. International Journal of Social Welfare, doi: 10.1111/ijsw.12202

México Evalúa. (2015). Prevención del delito en México: ¿Cuáles son las prioridades?. México: México Evalúa, Centro de Análisis de Políticas Públicas.

MCS-ENIGH. (2014). Módulo de condiciones socioeconómicas. Encuesta Nacional de Ingreso y Gasto en los Hogares. Resource document. México: Instituto Nacional de Estadística, Geografía e Informática. Retrieved July 20, 2015, from

http://www.inegi.org.mx/est/contenidos/proyectos/encuestas/hogares/modulos/mcs/mcs2014/default.aspx.

Mæstad, O., \& Norheim, O. (2012). A universal preference for equality in health? Reasons to reconsider properties of applied social welfare functions. Social Science \& Medicine, doi: 10.1016/j.socscimed.2012.07.001.

Noll, H.H. (2011). The Stiglitz-Sen-Fitoussi-Report: Old Wine in New Skins? Views from a social indicators perspective. Social Indicators Research, doi: 10.1007/s11205-010-9738-9.

OECD. (2011). How's Life? Measuring Well-being. Paris: Organization for Economic Co-operation and Development.

OECD. (2015). Measuring Well-being in Mexican States. Paris: Organization for Economic Co-operation and Development.

Osorio, J. (2012). Las causas estructurales de la violencia. Evaluación de algunas hipótesis. In: J. Aguilar, (Ed). Las Bases sociales del crimen organizado y la violencia en México (pp. 73-130). México: Centro de Investigación y Estudios en Seguridad.

Pearson, A. L., \& Breetzke, G. D. (2014). The Association Between the Fear of Crime, and Mental and Physical Wellbeing in New Zealand. Social Indicators Research, doi:10.1007/s11205-013-0489-2

Pena-Trapero, B. (2009). La medición del Bienestar Social: una revisión crítica. Estudios de Economía Aplicada, 27(2), 299-324.

Rodríguez-Martín, J. (2011). Propuesta de un índice de bienestar social en los países menos adelantados (PMA) de África. Economía, Sociedad y Territorio, XI(35) 19-40.

Russo, S., Roccato, M., \& Vieno, A. (2012). Criminal Victimization and Crime Risk Perception: A Multilevel Longitudinal Study. Social Indicators Research, doi:10.1007/s11205-012-0050-8

Sampson, R. J., Morenoff, J. D., \& Gannon-Rowley, T. (2002). Assessing "Neighborhood Effects": Social Processes and New Directions in Research. Annual Review of Sociology, doi:10.1146/annurev.soc.28.110601.141114

Sarracino, F. (2013). Determinants of subjective well-being in high and low income countries: Do happiness equations differ across countries? The Journal of Socio-Economics, doi: 10.1016/j.socec.2012.11.006. 
Sen, A. (1999). Development as Freedom. Oxford: Oxford University Press.

Sharkey, P., \& Faber, J. W. (2014) Where, When, Why, and For Whom Do Residential Contexts Matter? Moving Away from the Dichotomous Understanding of Neighborhood Effects. Annual Review of Sociology, doi:10.1146/annurev-soc-071913-043350

Shippee, N. D. (2012) Victimization, Fear of Crime, and Perceived Risk: Testing a Vulnerability Model of Personal Control. Sociological Perspectives, doi: 10.1525/sop.2012.55.1.117

Skogan, W. (2015) Disorder and Decline: The State of Research. Journal of Research in Crime and Delinquency, doi:10.1177/0022427815577836

Skogan, W. G., \& Maxfield, M. G. (1981). Coping with crime: individual and neighborhood reactions. Beverly Hills: Sage Publications.

Stafford, M., Chandola, T., \& Marmot, M. (2007). Association between fear of crime and mental health and physical functioning. American Journal of Public Health, 97(11), 2076-2081.

Stiglitz, J. E., Sen, A., \& Fitoussi, J.P. (2009). Report by the commission on the measurement of economic performance and social progress. Paris: The Commission on the Measurement of Economic Performance and Social Progress.

Tonon, G. (2012). Introduction to the Special Issue "International Wellbeing Index". Journal of Social Research \& Policy, 3(2) 5-6.

Torche, F., \& Villarreal, A. (2014). Prenatal Exposure to Violence and Birth Weight in Mexico: Selectivity, Exposure, and Behavioral Responses. American Sociological Review, doi:10.1177/0003122414544733

Vilalta, C. J. (2013). Determinant Factors in the Perception of Crime Related Insecurity in Mexico. InterAmerican Development Bank.

Wilson-Genderson, M., \& Pruchno, R. (2013). Effects of neighborhood violence and perceptions of neighborhood safety on depressive symptoms of older adults. Social Science \& Medicine, doi:10.1016/j.socscimed.2013.02.028

Wills-Herrera, E., Orozco, L. E., Forero-Pineda, C., Pardo, O., \& Andonova, V. (2011). The relationship between perceptions of insecurity, social capital and subjective well-being: Empirical evidences from areas of rural conflict in Colombia. Journal of Socio-Economics, doi: 10.1016/j.socec.2010.08.002

Wodtke, G. T., Harding, D. J., \& Elwert, F. (2011). Neighborhood Effects in Temporal Perspective: The Impact of Long-Term Exposure to Concentrated Disadvantage on High School Graduation. American Sociological Review, doi:10.1177/0003122411420816

Wright, E. M., Fagan, A. A., \& Pinchevsky, G. M. (2013). The effects of exposure to violence and victimization across life domains on adolescent substance use. Child Abuse \&amp; Neglect, doi:10.1016/j.chiabu.2013.04.010

Zhao, J. (2009). ICTs for Achieving Millennium Development Goals: Experiences of Connecting Rural China to the Internet. Knowledge, Technology \& Policy, doi: 10.1007/s12130-009-9071-2. 


\section{Appendix.}

Table 4. Indicators per unit of measure

\begin{tabular}{|c|c|c|c|c|c|c|c|c|c|c|c|c|c|c|}
\hline State & $\begin{array}{l}\text { Educational } \\
\text { Lag }\end{array}$ & $\begin{array}{l}\text { Access to } \\
\text { health } \\
\text { services }\end{array}$ & $\begin{array}{l}\text { Social } \\
\text { Securit } \\
\text { y }\end{array}$ & $\begin{array}{l}\text { Quality } \\
\text { of and } \\
\text { spaces } \\
\text { in the } \\
\text { home }\end{array}$ & $\begin{array}{l}\text { Basic } \\
\text { services } \\
\text { in the } \\
\text { home }\end{array}$ & $\begin{array}{l}\text { Food } \\
\text { insecurit } \\
\text { y }\end{array}$ & $\begin{array}{l}\text { Incom } \\
\mathrm{e}\end{array}$ & $\begin{array}{l}\text { Satisfact } \\
\text { ion with } \\
\text { life }\end{array}$ & Happiness & $\begin{array}{l}\text { Trust in } \\
\text { people }\end{array}$ & $\begin{array}{l}\text { Network } \\
\text { membership }\end{array}$ & $\begin{array}{l}\text { Perception } \\
\text { of } \\
\text { insecurity }\end{array}$ & $\begin{array}{l}\text { Victims } \\
\text { of crime }\end{array}$ & Homicides \\
\hline Aguascalientes & 14.35 & 12.48 & 43.19 & 3.31 & 3.60 & 21.55 & 12.91 & 7.74 & 5.97 & 2.53 & 0.84 & 49.10 & 26.78 & 8 \\
\hline Baja California & 15.41 & 19.35 & 51.84 & 10.65 & 12.10 & 17.18 & 9.70 & 8.27 & 6.18 & 2.46 & 0.76 & 53.69 & 39.51 & 34.40 \\
\hline Baja California Sur & 14.87 & 14.21 & 46.63 & 16.47 & 12.40 & 24.57 & 10.56 & 8.30 & 6.05 & 2.57 & 0.68 & 39.26 & 24.75 & 14.90 \\
\hline Campeche & 18.78 & 12.47 & 60.14 & 19.54 & 38.80 & 24.26 & 19.20 & 7.77 & 6.04 & 2.25 & 0.82 & 58.92 & 23.71 & 17.90 \\
\hline Coahuila & 12.49 & 15.57 & 34.20 & 4.98 & 5.60 & 22.03 & 11.80 & 8.04 & 6.19 & 2.71 & 0.77 & 78.50 & 24.04 & 41.30 \\
\hline Colima & 17.46 & 12.70 & 51.91 & 10.91 & 9.60 & 25.44 & 10.57 & 7.78 & 6.10 & 2.55 & 0.89 & 56.87 & 22.06 & 41.20 \\
\hline Chiapas & 30.67 & 20.65 & 82.76 & 26.90 & 57.40 & 27.52 & 48.46 & 7.94 & 6.20 & 2.26 & 0.59 & 62.09 & 16.45 & 22 \\
\hline Chihuahua & 17.26 & 14.57 & 43.36 & 7.92 & 7.90 & 18.70 & 17.85 & 8.33 & 6.25 & 2.28 & 0.62 & 75.17 & 27.34 & 51 \\
\hline Mexico City & 8.84 & 19.94 & 46.28 & 5.44 & 1.70 & 11.69 & 8.20 & 8.45 & 6.18 & 1.76 & 0.64 & 77.61 & 33.07 & 26.90 \\
\hline Durango & 15.50 & 16.54 & 51.26 & 5.76 & 13.00 & 19.94 & 20.75 & 8.19 & 6.23 & 2.39 & 0.57 & 73.47 & 22.16 & 33.70 \\
\hline Guanajuato & 20.96 & 15.42 & 57.85 & 9.77 & 14.90 & 22.94 & 17.91 & 7.94 & 6.09 & 2.36 & 0.46 & 64.80 & 27.29 & 24.50 \\
\hline Guerrero & 26.78 & 19.24 & 78.10 & 32.89 & 58.00 & 38.46 & 35.58 & 7.75 & 6.02 & 2.31 & 0.59 & 78.92 & 26 & 60.20 \\
\hline Hidalgo & 19.05 & 17.31 & 68.90 & 9.20 & 27.00 & 31.68 & 24.68 & 7.96 & 6.16 & 2.07 & 0.59 & 65.50 & 19.89 & 14.80 \\
\hline Jalisco & 17.69 & 19.10 & 49.57 & 6.56 & 7.00 & 16.53 & 11.20 & 7.84 & 5.97 & 2.60 & 0.65 & 67.97 & 33.03 & 31.80 \\
\hline México & 15.30 & 19.67 & 60.63 & 10.29 & 12.40 & 21.29 & 20.07 & 7.87 & 6.21 & 2.29 & 0.51 & 92.64 & 47.78 & 40.10 \\
\hline Michoacán & 27.57 & 26.21 & 71.26 & 15.44 & 26.60 & 34.66 & 24.42 & 7.65 & 5.93 & 2.35 & 0.63 & 81.99 & 20 & 30.60 \\
\hline Morelos & 16.56 & 16.63 & 66.20 & 13.42 & 24.60 & 26.85 & 20.53 & 7.66 & 6.07 & 2.40 & 0.76 & 89.05 & 26.15 & 49.70 \\
\hline Nayarit & 17.36 & 16.26 & 54.35 & 10.12 & 15.30 & 24.14 & 18.80 & 7.92 & 6.11 & 2.83 & 0.77 & 51.10 & 18.53 & 32 \\
\hline Nuevo León & 10.78 & 13.67 & 33.44 & 4.56 & 4.30 & 14.16 & 6.37 & 8.20 & 6.29 & 2.66 & 0.73 & 72.97 & 26.52 & 34.20 \\
\hline Oaxaca & 27.20 & 19.93 & 77.91 & 24.53 & 60.50 & 36.11 & 42.11 & 7.46 & 5.93 & 2.25 & 0.62 & 77.08 & 16.29 & 34.10 \\
\hline Puebla & 22.95 & 21.17 & 75.15 & 18.93 & 30.60 & 23.85 & 31.85 & 7.58 & 6.08 & 2.20 & 0.50 & 63.58 & 23.58 & 20.10 \\
\hline Querétaro & 16.41 & 15.82 & 54.31 & 8.94 & 14.80 & 15.77 & 12.27 & 8.27 & 6.32 & 2.61 & 0.68 & 38.54 & 23.55 & 15 \\
\hline Quintana Roo & 15.15 & 18.46 & 51.49 & 18.42 & 18.10 & 23.24 & 14.30 & 7.97 & 6.18 & 2.45 & 0.84 & 66.95 & 26.52 & 22.50 \\
\hline San Luis Potosí & 18.44 & 10.71 & 59.12 & 11.00 & 28.10 & 21.65 & 23.22 & 7.95 & 6.16 & 2.44 & 0.73 & 73.13 & 25.71 & 23.10 \\
\hline Sinaloa & 19.10 & 15.20 & 49.33 & 10.78 & 18.00 & 29.64 & 13.47 & 7.87 & 6.11 & 2.78 & 0.64 & 72.06 & 23.59 & 45.10 \\
\hline Sonora & 12.11 & 14.42 & 41.80 & 10.13 & 8.90 & 24.86 & 9.69 & 7.97 & 6.14 & 2.99 & 0.91 & 57.19 & 27.39 & 33.10 \\
\hline Tabasco & 16.96 & 16.92 & 72.75 & 13.41 & 43.90 & 45.03 & 17.87 & 7.92 & 6.12 & 2.50 & 0.69 & 86.07 & 22.73 & 16 \\
\hline Tamaulipas & 15.96 & 15.02 & 45.52 & 8.21 & 11.50 & 19.51 & 16.14 & 8.30 & 6.33 & 2.77 & 0.70 & 83.91 & 17.57 & 38.50 \\
\hline Tlaxcala & 14.93 & 17.48 & 71.47 & 9.42 & 12.10 & 24.00 & 27.05 & 7.83 & 6.06 & 2.31 & 0.70 & 59.99 & 21.92 & 15.30 \\
\hline Veracruz & 27.80 & 21.73 & 68.46 & 16.84 & 40.00 & 30.00 & 29.18 & 7.74 & 6.04 & 2.28 & 0.60 & 80.71 & 20.25 & 20.10 \\
\hline Yucatán & 21.82 & 14.48 & 54.45 & 17.48 & 40.40 & 18.37 & 20.72 & 8.02 & 6.24 & 2.58 & 0.74 & 29.48 & 18.44 & 7.10 \\
\hline Zacatecas & 21.61 & 14.86 & 63.37 & 4.89 & 3.60 & 16.83 & 26.71 & 8.08 & 6.17 & 2.48 & 0.84 & 80.32 & 20.86 & 31.5 \\
\hline
\end{tabular}

Source: Authors, based on surveys: MCS-ENIGH, 2014; BIARE, 2014; ENVIPE, 2014; INEGI, 2013.

Table 5. Matrix of indicators weighed without insecurity. 


\begin{tabular}{|c|c|c|c|c|c|c|c|c|c|c|c|c|}
\hline Entity & $\begin{array}{l}\text { Social } \\
\text { Security }\end{array}$ & $\begin{array}{l}\text { Access to } \\
\text { health } \\
\text { services }\end{array}$ & $\begin{array}{l}\text { Satisfaction } \\
\text { with life }\end{array}$ & $\begin{array}{l}\text { Network } \\
\text { membership }\end{array}$ & $\begin{array}{l}\text { Food } \\
\text { insecurity }\end{array}$ & $\begin{array}{l}\text { Trust in } \\
\text { people }\end{array}$ & Happiness & $\begin{array}{l}\text { Educational } \\
\text { Lag }\end{array}$ & $\begin{array}{l}\text { Basic services } \\
\text { in the home }\end{array}$ & Income & $\begin{array}{l}\text { Quality of and } \\
\text { spaces in the } \\
\text { home }\end{array}$ & DP2 \\
\hline Nuevo León & $3.85^{\mathrm{a}}$ & $2.25^{\mathrm{b}}$ & 1.64 & 1.24 & 1.85 & 1.59 & 1.28 & 1.10 & 0.92 & 1.12 & 0.97 & 17.82 \\
\hline Sonora & $3.20^{\mathrm{a}}$ & 2.12 & 1.12 & 2.03 & 1.21 & $2.17^{\mathrm{b}}$ & 0.72 & 1.03 & 0.85 & 1.03 & 0.78 & 16.26 \\
\hline Coahuila & $3.79^{\mathrm{a}}$ & $1.91^{\mathrm{b}}$ & 1.28 & 1.38 & 1.38 & 1.67 & 0.90 & 1.01 & 0.90 & 0.98 & 0.96 & 16.15 \\
\hline Tamaulipas & $2.91^{\mathrm{a}}$ & $2.01^{\mathrm{b}}$ & 1.86 & 1.10 & 1.53 & 1.77 & 1.42 & 0.82 & 0.80 & 0.86 & 0.85 & 15.93 \\
\hline Querétaro & $2.22^{\mathrm{a}}$ & $1.87^{\mathrm{b}}$ & 1.79 & 0.98 & 1.76 & 1.50 & 1.38 & 0.79 & 0.75 & 0.96 & 0.82 & 14.82 \\
\hline Chihuahua & $3.08^{\mathrm{a}}$ & $2.09^{\mathrm{b}}$ & 1.92 & 0.70 & 1.58 & 0.91 & 1.14 & 0.74 & 0.86 & 0.82 & 0.86 & 14.70 \\
\hline Aguascalientes & $3.09^{\mathrm{a}}$ & $2.47^{\mathrm{b}}$ & 0.64 & 1.71 & 1.41 & 1.36 & 0.13 & 0.90 & 0.93 & 0.95 & 1.01 & 14.61 \\
\hline Baja California Sur & $2.82^{\mathrm{a}}$ & $2.16^{\mathrm{b}}$ & 1.85 & 0.98 & 1.23 & 1.42 & 0.42 & 0.88 & 0.79 & 1.01 & 0.56 & 14.11 \\
\hline Mexico City & $2.85^{\mathrm{a}}$ & 1.13 & $2.18^{\mathrm{b}}$ & 0.83 & 2.00 & $0.00^{\mathrm{c}}$ & 0.86 & 1.21 & 0.96 & 1.07 & 0.94 & 14.03 \\
\hline Baja California & $2.41^{\mathrm{a}}$ & 1.23 & $1.80^{\mathrm{b}}$ & 1.36 & 1.67 & 1.22 & 0.89 & 0.85 & 0.79 & 1.03 & 0.76 & 14.02 \\
\hline Colima & $2.41^{\mathrm{b}}$ & $2.43^{\mathrm{a}}$ & 0.71 & 1.92 & 1.18 & 1.40 & 0.61 & 0.73 & 0.83 & 1.01 & 0.75 & 13.97 \\
\hline Durango & $2.46^{\mathrm{a}}$ & $1.74^{\mathrm{b}}$ & 1.62 & 0.49 & 1.51 & 1.11 & 1.05 & 0.84 & 0.78 & 0.74 & 0.93 & 13.27 \\
\hline Nayarit & $2.22^{\mathrm{a}}$ & 1.79 & 1.02 & 1.40 & 1.25 & $1.88^{\mathrm{b}}$ & 0.64 & 0.74 & 0.74 & 0.79 & 0.78 & 13.24 \\
\hline Yucatán & $2.21^{\mathrm{a}}$ & $2.11^{\mathrm{b}}$ & 1.25 & 1.26 & 1.60 & 1.44 & 1.10 & 0.49 & 0.33 & 0.74 & 0.53 & 13.07 \\
\hline Quintana Roo & $2.44^{\mathrm{a}}$ & 1.39 & 1.14 & $1.71^{\mathrm{b}}$ & 1.31 & 1.22 & 0.89 & 0.86 & 0.69 & 0.91 & 0.50 & 13.06 \\
\hline San Luis Potosí & $1.85^{\mathrm{b}}$ & $2.79^{\mathrm{a}}$ & 1.09 & 1.24 & 1.40 & 1.20 & 0.81 & 0.68 & 0.53 & 0.67 & 0.75 & 13.01 \\
\hline Sinaloa & $2.61^{\mathrm{a}}$ & $1.98^{\mathrm{b}}$ & 0.91 & 0.81 & 0.92 & 1.79 & 0.63 & 0.64 & 0.70 & 0.93 & 0.76 & 12.68 \\
\hline Jalisco & $2.59^{\mathrm{a}}$ & 1.28 & 0.85 & 0.87 & $1.71^{\mathrm{b}}$ & 1.47 & 0.14 & 0.72 & 0.88 & 0.99 & 0.90 & 12.40 \\
\hline Zacatecas & 1.51 & $2.04^{\mathrm{a}}$ & 1.37 & 0.72 & $1.69^{\mathrm{b}}$ & 1.27 & 0.82 & 0.50 & 0.77 & 0.58 & 0.96 & 12.24 \\
\hline Campeche & $1.77^{\mathrm{b}}$ & $2.47^{\mathrm{a}}$ & 0.68 & 1.64 & 1.25 & 0.87 & 0.37 & 0.66 & 0.36 & 0.78 & 0.46 & 11.30 \\
\hline Guanajuato & $1.95^{\mathrm{a}}$ & $1.94^{\mathrm{b}}$ & 1.07 & $0.00^{\mathrm{c}}$ & 1.33 & 1.06 & 0.57 & 0.54 & 0.75 & 0.81 & 0.79 & 10.80 \\
\hline México & $1.73^{\mathrm{a}}$ & $1.17^{\mathrm{b}}$ & 0.91 & 0.23 & 1.42 & 0.93 & 1.00 & 0.85 & 0.79 & 0.76 & 0.78 & 10.56 \\
\hline Morelos & 1.29 & $1.72^{\mathrm{a}}$ & 0.45 & $1.36^{\mathrm{b}}$ & 1.09 & 1.13 & 0.48 & 0.78 & 0.59 & 0.74 & 0.67 & 10.31 \\
\hline Tlaxcala & 0.88 & $1.57^{\mathrm{a}}$ & 0.82 & 1.07 & $1.26^{\mathrm{b}}$ & 0.97 & 0.45 & 0.87 & 0.79 & 0.57 & 0.80 & 10.07 \\
\hline Hidalgo & 1.08 & $1.60^{\mathrm{a}}$ & $1.11^{\mathrm{b}}$ & 0.61 & 0.80 & 0.54 & 0.80 & 0.64 & 0.55 & 0.63 & 0.81 & 9.19 \\
\hline Tabasco & 0.78 & $1.67^{\mathrm{a}}$ & 1.02 & 1.03 & $0.00^{c}$ & $1.30^{\mathrm{b}}$ & 0.68 & 0.76 & 0.27 & 0.82 & 0.67 & 9.00 \\
\hline Veracruz & $1.12^{\mathrm{a}}$ & 0.80 & 0.62 & 0.64 & 0.90 & $0.92^{\mathrm{b}}$ & 0.38 & 0.16 & 0.34 & 0.51 & 0.55 & 6.95 \\
\hline Puebla & 0.59 & $0.90^{\mathrm{b}}$ & 0.28 & 0.18 & $1.27^{\mathrm{a}}$ & 0.77 & 0.53 & 0.43 & 0.49 & 0.44 & 0.48 & 6.36 \\
\hline Chiapas & $0.00^{\mathrm{c}}$ & 1.00 & $1.08^{\mathrm{a}}$ & 0.57 & $1.05^{\mathrm{b}}$ & 0.88 & 0.93 & $0.00^{\mathrm{c}}$ & 0.05 & $0.00^{\mathrm{c}}$ & 0.21 & 5.76 \\
\hline Michoacán & $0.90^{\mathrm{b}}$ & $0.00^{\mathrm{c}}$ & 0.42 & 0.75 & 0.62 & $1.04^{\mathrm{a}}$ & $0.00^{\mathrm{c}}$ & 0.17 & 0.56 & 0.64 & 0.60 & 5.70 \\
\hline Guerrero & 0.36 & $1.25^{\mathrm{a}}$ & 0.65 & 0.58 & 0.39 & $0.96^{\mathrm{b}}$ & 0.32 & 0.22 & 0.04 & 0.34 & $0.00^{\mathrm{c}}$ & 5.12 \\
\hline Oaxaca & 0.38 & $1.13^{\mathrm{a}}$ & $0.00^{\mathrm{c}}$ & 0.71 & 0.54 & $0.87^{\mathrm{b}}$ & $0.00^{\mathrm{c}}$ & 0.19 & $0.00^{\mathrm{c}}$ & 0.17 & 0.29 & 4.27 \\
\hline
\end{tabular}

Source: Authors. a: Highest-contributing indicator; b: second-highest contributor; c: no contribution. 
Table 6. Matrix of indicators weighed with insecurity.

\begin{tabular}{|c|c|c|c|c|c|c|c|c|c|c|c|c|c|c|c|}
\hline State & $\begin{array}{l}\text { Social } \\
\text { Security }\end{array}$ & $\begin{array}{l}\text { Access } \\
\text { to health } \\
\text { services }\end{array}$ & $\begin{array}{l}\text { Perception } \\
\text { of } \\
\text { insecurity }\end{array}$ & $\begin{array}{l}\text { Satisfaction } \\
\text { with life }\end{array}$ & $\begin{array}{l}\text { Trust in } \\
\text { people }\end{array}$ & $\begin{array}{l}\text { Network } \\
\text { membership }\end{array}$ & $\begin{array}{l}\text { Food } \\
\text { insecurity }\end{array}$ & $\begin{array}{l}\text { Victims } \\
\text { of crime }\end{array}$ & Homicides & Happiness & $\begin{array}{l}\text { Educational } \\
\text { Lag }\end{array}$ & $\begin{array}{l}\text { Basic } \\
\text { services } \\
\text { in the } \\
\text { home }\end{array}$ & Income & $\begin{array}{l}\text { Quality } \\
\text { of and } \\
\text { spaces } \\
\text { in the } \\
\text { home }\end{array}$ & DP2 \\
\hline Nuevo León & $3.85^{\mathrm{a}}$ & $2.42^{\mathrm{b}}$ & 0.73 & 1.61 & 1.87 & 1.24 & 1.85 & 1.34 & 0.79 & 1.09 & 1.10 & 0.92 & 1.12 & 0.92 & 20.85 \\
\hline Sonora & $3.20^{\mathrm{a}}$ & 2.28 & 1.31 & 1.11 & $2.55^{\mathrm{b}}$ & 2.04 & 1.21 & 1.28 & 0.82 & 0.61 & 1.03 & 0.85 & 1.03 & 0.74 & 20.05 \\
\hline Querétaro & $2.22^{\mathrm{a}}$ & $2.01^{\mathrm{b}}$ & 2.00 & 1.77 & 1.76 & 0.98 & 1.76 & 1.53 & 1.37 & 1.17 & 0.79 & 0.75 & 0.96 & 0.77 & 19.84 \\
\hline Aguascalientes & $3.09^{\mathrm{a}}$ & $2.65^{\mathrm{b}}$ & 1.61 & 0.63 & 1.60 & 1.72 & 1.41 & 1.32 & 1.58 & 0.11 & 0.90 & 0.93 & 0.95 & 0.96 & 19.46 \\
\hline Baja California Sur & $2.82^{\mathrm{a}}$ & $2.32^{\mathrm{b}}$ & 1.98 & 1.83 & 1.67 & 0.98 & 1.23 & 1.45 & 1.37 & 0.35 & 0.88 & 0.79 & 1.01 & 0.53 & 19.20 \\
\hline Yucatán & 2.21 & $2.27^{\mathrm{b}}$ & $2.34^{\mathrm{a}}$ & 1.24 & 1.70 & 1.26 & 1.60 & 1.85 & 1.61 & 0.94 & 0.49 & 0.33 & 0.74 & 0.50 & 19.06 \\
\hline Tamaulipas & $2.91^{\mathrm{a}}$ & $2.16^{\mathrm{b}}$ & 0.32 & 1.84 & 2.08 & 1.10 & 1.53 & 1.90 & 0.66 & 1.20 & 0.82 & 0.80 & 0.86 & 0.80 & 18.99 \\
\hline Coahuila & $3.79^{\mathrm{a}}$ & $2.06^{\mathrm{b}}$ & 0.52 & 1.26 & 1.96 & 1.38 & 1.38 & 1.50 & 0.57 & 0.77 & 1.01 & 0.90 & 0.98 & 0.90 & 18.98 \\
\hline Nayarit & $2.22^{\mathrm{a}}$ & 1.92 & 1.54 & 1.00 & $2.21^{\mathrm{b}}$ & 1.40 & 1.25 & 1.84 & 0.85 & 0.54 & 0.74 & 0.74 & 0.79 & 0.74 & 17.79 \\
\hline Colima & $2.41^{\mathrm{b}}$ & $2.61^{\mathrm{a}}$ & 1.32 & 0.70 & 1.64 & 1.92 & 1.18 & 1.62 & 0.57 & 0.52 & 0.73 & 0.83 & 1.01 & 0.71 & 17.78 \\
\hline Chihuahua & $3.08^{\mathrm{a}}$ & $2.25^{\mathrm{b}}$ & 0.65 & 1.89 & 1.07 & 0.70 & 1.58 & 1.29 & 0.28 & 0.96 & 0.74 & 0.86 & 0.82 & 0.81 & 16.98 \\
\hline Baja California & $2.41^{\mathrm{a}}$ & 1.32 & 1.44 & $1.77^{\mathrm{b}}$ & 1.44 & 1.36 & 1.67 & 0.52 & 0.78 & 0.75 & 0.85 & 0.79 & 1.03 & 0.72 & 16.87 \\
\hline Quintana Roo & $2.44^{\mathrm{a}}$ & 1.50 & 0.95 & 1.12 & 1.44 & $1.71^{\mathrm{b}}$ & 1.31 & 1.34 & 1.14 & 0.75 & 0.86 & 0.69 & 0.91 & 0.47 & 16.64 \\
\hline Durango & $2.46^{\mathrm{a}}$ & $1.87^{\mathrm{b}}$ & 0.71 & 1.60 & 1.30 & 0.49 & 1.51 & 1.61 & 0.80 & 0.89 & 0.84 & 0.78 & 0.74 & 0.88 & 16.49 \\
\hline San Luis Potosí & $1.85^{\mathrm{b}}$ & $2.99^{\mathrm{a}}$ & 0.72 & 1.08 & 1.41 & 1.24 & 1.40 & 1.39 & 1.12 & 0.69 & 0.68 & 0.53 & 0.67 & 0.71 & 16.48 \\
\hline Mexico City & $2.85^{\mathrm{a}}$ & 1.21 & 0.56 & $2.15^{\mathrm{b}}$ & $0.00^{\mathrm{c}}$ & 0.83 & 2.00 & 0.93 & 1.01 & 0.73 & 1.21 & 0.96 & 1.07 & 0.89 & 16.40 \\
\hline Sinaloa & $2.61^{\mathrm{a}}$ & $2.13^{\mathrm{b}}$ & 0.76 & 0.89 & 2.11 & 0.81 & 0.92 & 1.52 & 0.46 & 0.54 & 0.64 & 0.70 & 0.93 & 0.71 & 15.74 \\
\hline Campeche & $1.77^{\mathrm{b}}$ & $2.66^{\mathrm{a}}$ & 1.25 & 0.67 & 1.03 & 1.64 & 1.25 & 1.52 & 1.28 & 0.31 & 0.66 & 0.36 & 0.78 & 0.43 & 15.60 \\
\hline Zacatecas & 1.51 & $2.19^{\mathrm{a}}$ & 0.46 & 1.35 & 1.49 & 0.72 & 1.69 & $1.70^{\mathrm{b}}$ & 0.87 & 0.70 & 0.50 & 0.77 & 0.58 & 0.91 & 15.44 \\
\hline Jalisco & $2.59^{\mathrm{a}}$ & 1.37 & 0.91 & 0.84 & $1.73^{\mathrm{b}}$ & 0.87 & 1.71 & 0.93 & 0.86 & 0.12 & 0.72 & 0.88 & 0.99 & 0.85 & 15.38 \\
\hline Tlaxcala & 0.88 & $1.69^{\mathrm{a}}$ & 1.21 & 0.81 & 1.14 & 1.07 & 1.26 & $1.63^{\mathrm{b}}$ & 1.36 & 0.38 & 0.87 & 0.79 & 0.57 & 0.76 & 14.43 \\
\hline Guanajuato & $1.95^{\mathrm{b}}$ & $2.09^{\mathrm{a}}$ & 1.03 & 1.05 & 1.25 & $0.00^{\mathrm{c}}$ & 1.33 & 1.29 & 1.08 & 0.48 & 0.54 & 0.75 & 0.81 & 0.75 & 14.39 \\
\hline Hidalgo & 1.08 & $1.72^{\mathrm{b}}$ & 1.00 & 1.10 & 0.64 & 0.61 & 0.80 & $1.76^{\mathrm{a}}$ & 1.37 & 0.68 & 0.64 & 0.55 & 0.63 & 0.77 & 13.36 \\
\hline Tabasco & 0.78 & $1.79^{\mathrm{a}}$ & 0.24 & 1.01 & 1.53 & 1.03 & $0.00^{c}$ & $1.58^{\mathrm{b}}$ & 1.34 & 0.57 & 0.76 & 0.27 & 0.82 & 0.63 & 12.36 \\
\hline Morelos & 1.29 & $1.85^{\mathrm{a}}$ & 0.13 & 0.44 & 1.33 & 1.36 & 1.09 & $1.36^{\mathrm{b}}$ & 0.32 & 0.41 & 0.78 & 0.59 & 0.74 & 0.63 & 12.34 \\
\hline México & $1.73^{\mathrm{a}}$ & 1.26 & $0.00^{\mathrm{c}}$ & 0.90 & 1.09 & 0.23 & $1.43^{\mathrm{b}}$ & $0.00^{\mathrm{c}}$ & 0.61 & 0.85 & 0.85 & 0.79 & 0.76 & 0.73 & 11.21 \\
\hline Veracruz & 1.12 & 0.86 & 0.44 & 0.61 & 1.09 & 0.64 & 0.90 & $1.73^{\mathrm{a}}$ & $1.21^{\mathrm{b}}$ & 0.33 & 0.16 & 0.34 & 0.51 & 0.52 & 10.46 \\
\hline Puebla & 0.59 & 0.97 & 1.08 & 0.27 & 0.90 & 0.18 & $1.27^{\mathrm{b}}$ & $1.52^{\mathrm{a}}$ & 1.21 & 0.45 & 0.43 & 0.49 & 0.44 & 0.45 & 10.27 \\
\hline Chiapas & $0.00^{c}$ & 1.07 & 1.13 & 1.06 & 1.04 & 0.57 & 1.05 & $1.97^{\mathrm{a}}$ & $1.15^{\mathrm{b}}$ & 0.79 & $0.00^{\mathrm{c}}$ & 0.05 & $0.00^{\mathrm{c}}$ & 0.19 & 10.09 \\
\hline Michoacán & 0.90 & $0.00^{\mathrm{c}}$ & 0.39 & 0.41 & $1.23^{\mathrm{b}}$ & 0.75 & 0.62 & $1.75^{\mathrm{a}}$ & 0.89 & $0.00^{\mathrm{c}}$ & 0.17 & 0.56 & 0.64 & 0.56 & 8.88 \\
\hline Oaxaca & 0.38 & $1.21^{\mathrm{b}}$ & 0.58 & $0.00^{\mathrm{c}}$ & 1.02 & 0.71 & 0.54 & $1.98^{\mathrm{a}}$ & 0.79 & $0.00^{\mathrm{c}}$ & 0.19 & $0.00^{c}$ & 0.17 & 0.27 & 7.84 \\
\hline Guerrero & 0.36 & $1.35^{\mathrm{b}}$ & 0.51 & 0.64 & 1.13 & 0.58 & 0.39 & $1.37^{\mathrm{a}}$ & $0.00^{\mathrm{c}}$ & 0.27 & 0.22 & 0.04 & 0.34 & $0.00^{\mathrm{c}}$ & 7.21 \\
\hline
\end{tabular}

Source: Authors. a: Highest-contributing indicator; b: second-highest contributor; c:no contribution. 